\title{
Some structural details of the hind wings detected in staphylinids of 7 subfamilies (Coleoptera)
}

\begin{abstract}
Study of 41 species provided information as follows: (a) a setigerous lobe is located at the costal margin in every species in the subf. Staphylininae; (b) a setal comb occupies the same margin in Xantholinini and Omaliinae; (c) one or more spinulae do line the anal field of all Omaliinae and most Oxytelinae, Tachyporinae and Aleocharinae; (d) number of these spinulae in Aleocharinae ranges from 1 up to about 100 and is null in two species. Hypothetically, a functional importance may be attributed to both the setigerous lobe, which suggests a mechanical receptor for wing folding control, and to the flabellum-like anal field of the Aleochara, which looks as a device affecting the flying trim.

Riassunto - Dettagli strutturali delle ali posteriori in stafilinidi di 7 sottofamiglie (Coleoptera)

Lo studio delle ali posteriori in 41 specie ha fornito le seguenti informazioni: (a) un "lobo setigero" occupa il margine costale in tutte le specie della subf. Staphylininae; (b) un "pettine costale" di setole spiniformi si trova in Staphylininae-Xantholininae e Omaliinae; (c) il campo anale reca una o più spinale nella maggior parte delle specie esaminate delle sottofamiglie Proteininae, Omaliinae, Oxytelinae, Tachyporinae e Aleocharinae. Le tabelle riassumono: (A) il numero di unità nel lobo setigero delle Staphylininae; (B) la presenza/assenza e il numero delle spinule del campo anale nelle varie sottofamiglie; (C) il numero delle spinule del campo anale nelle Aleocharinae. La variabilità interspecifica in quest'ultima sottofamiglia si estende in una gamma da 1 fino a più di 100 e prevede anche l'assenza delle spinule in tre specie. Dal punto di vista funzionale, si ipotizza che il lobo setigero delle Staphylininae rappresenti un propriocettore per il controllo del ripiegamento dell'ala e che la struttura a ventaglio del campo anale delle Aleochara possa avere importanza nell'assetto del volo.
\end{abstract}

Key words: costal margin, anal field, unpublished structures, supposed adaptations.

\section{INTRODUCTION}

Clever authors, such as d'Orchimont (1920), Graham (1922), Forbes (1922), Crowson (1967) and Wallace \& Fox (1975) have studied the wings of the Insecta; they 
underlined the main features of different orders and did speculate on the wing evolution also on the basis of fossil material. Authors' interest about the Coleoptera was mainly paid to the hind wings and especially to folding patterns of them. Hind wings of the staphylinids were studied to some extent by Botturi (1978), Hammond (1979) and Kukalova'Peck \& Lawrence (1993); anyhow, some details of them did remain to be described. This contribution deals with 41 species of staphylinids, most of which were identified thanks to the courtesy of Dr. Adriano Zanetti (Verona Museum). The two species of Stenus were courteously identified by Dr. Volker Assing (Hannover).

\section{MATERIALS AND METHODS}

Hind wings were obtained either from specimens collected directly in the field or from specimens preserved in liquids or dry collections. In every case, specimens were treated in a bath 1:1 of glycerol and ethanol 70\% for 3-4 hours at least. Examined species are listed behind, according to the checklists of Ciceroni et al. (1995) and Smetana (2004).

Proteininae: Megarthrus affinis Miller, Metopsia clypeata (Müller), Proteinus atomarius Erichson ( $\mathrm{n}=1)$. Omaliinae: Eusphalerum montivagum (Heer), Omalium riparium Thompson, Paraphloeostiba gayndahensis (MacLeay). Oxytelinae: Anotylus inustus (Gravenhorst), Bledius furcatus (Olivier) $(\mathrm{n}=1)$, Oxytelus piceus (Linnaeus), Platystethus nitens (C. Sahlberg). Steninae: Stenus aceris Stephens $(\mathrm{n}=2)$, S. longitarsis Thomson $(\mathrm{n}=2)$. Paederinae: Paederus fuscipes Curtis, Pseudolathra lusitanica (Erichson), Rugilus orbiculatus (Paykull). Staphylininae-Staphylinini: Creophilus maxillosus (Linnaeus), Emus hirtus (Linnaeus) (n=2), Ocypus olens (O. Müller). StaphylininaePhilonthini: Cafius xantholoma (Gravenhorst), Gabronthus maritimus (Motschulsky), Philonthus intermedius (Lacordaire). Staphylininae-Quediini: Quedius pallipes P. Lucas. Staphylininae-Xantholinini: Leptacinus othioides Baudi, Megalinus glabratus (Gravenhorst). Tachyporinae: Cilea silphoides (Linnaeus), Tachinus flavolimbatus Pandellé, Tachyporus hypnorum (Fabricius). Aleocharinae: Aleochara bipustulata (Linnaeus), A curtula (Goeze) ( $\mathrm{n}=2)$, A tristis Gravenhorst, Atheta aeneicollis (Sharp), A. elongatula (Gravenhorst) $(\mathrm{n}=2)$, A. inquinula (Gravenhorst), Cordalia obscura (Gravenhorst), Diestota guadalupensis Pace $(\mathrm{n}=1)$, Halobrecta flavipes Thomson $(\mathrm{n}=2)$, Myrmecopora uvida (Erichson), Nehemitropia lividipennis (Mannerheim), Oligota parva Kraatz, Thecturota marchii (Dodero), Trichiusa immigrata Lohse (n=2).

Four specimens (both wings) were examined for each species, except for the minor numbers indicated in the above list. Exposition of results starts from a new analysis of the hind wings of Creophilus maxillosus, which has been already examined by Kukalova'Peck \& Lawrence (l.c.). The morphological terms - costal margin, radial spring, anal field - are in agreement with these authors.

\section{RESULTS}

A new morphological analysis of the hind wings of Creophilus maxillosus (Staphylininae-Staphylinini) allows to observed on the costal margin a new structure, 
which is indicated in Fig. 1.A as "setigerous lobe". It is a small membranous protuberance, located behind the "marginal blade" of the latter. This setigerous lobe can be easily recognized in every other examined species of the subf. Staphylininae, because it gives some short setae. Number of these is somewhat variable according to species (Figs. 1-3); within the tribe Staphylinini they are $20 \pm 5 \%$ in both Creophilus maxillosus and Ocypus olens (Fig. 1.B), whereas there are about 100 setae in Emus hirtus (Fig. 2.B). Further values are listed in Tab. A.

Tab. A - Hind wings in the examined species of the subf. Staphylininae: approximate number of the setae of the "setigerous lobe".

\begin{tabular}{|l|c|}
\hline \multicolumn{1}{|c|}{ Tribe and species } & No. of setae \\
\hline Staphylinini & 20 \\
\hline Creophilus maxillosus & 100 \\
\hline Emus hirtus & 20 \\
\hline Ocypus olens & 28 \\
\hline Philonthini & 8 \\
\hline Cafius xantholoma & 16 \\
\hline Gabronthus maritimus & 13 \\
\hline Philonthus intermedius & \\
\hline Remus filum & 20 \\
\hline Quediini & \\
\hline Quedius pallipes & 14 \\
\hline Xantholinini & \\
\hline Leptacinus othioides & \\
\hline Megalinus glabratus & \\
\hline
\end{tabular}

A second new structure occupies the costal margin in the two examined members of the tribe Xantholinini; it is indicated as "setal comb" in Fig. 3 and consists in a series of spine-like setae, somewhat uniform in their length and disposed in a single row; it includes about 30 setae in Leptacinus othioides and more than 200 setae in Megalinus glabratus.

A similar comb has been found along the costal margin in every examined species of the subf. Omaliinae (Figs. 4 and 5.A). Moreover, the anal field of the Omaliinae bears a tuft of long spinulae (= "anal field spinulae"), whose number ranges from 12 to 20 . Although it is clearly delimited by an indentation, the anal field of all Staphylininae, Steninae and Paederinae is lacking of such an equipment of spinulae (Figs. 5.B and 6). Anyhow, a similar equipment is present in the subf. Proteininae (Fig. 7), both in the normal wings of Proteinus atomarius and Megarthrus affinis and in the rudimentary 


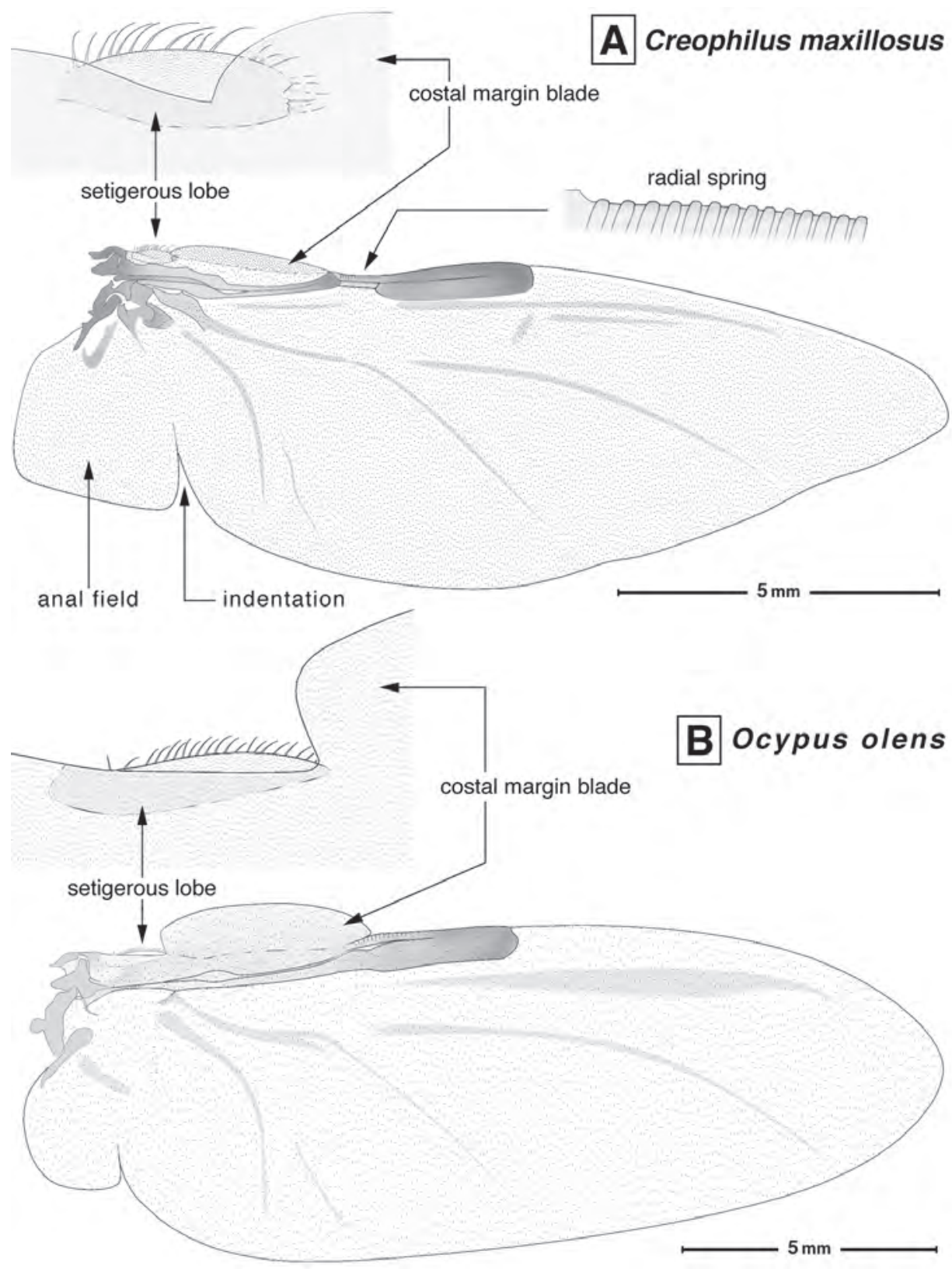

Fig. 1 - Subf. Staphylininae: entire hind wing and details in two species of the tribe Staphylinini. 


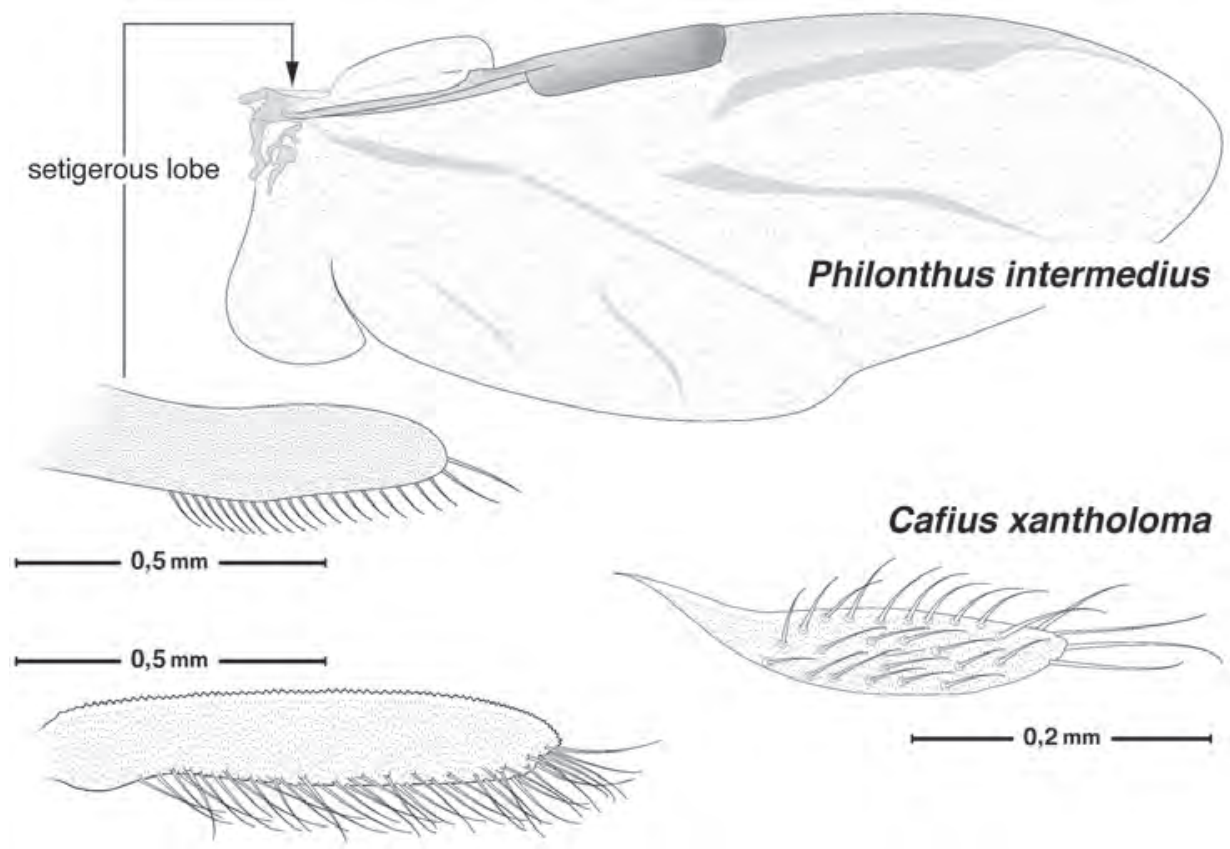

Emus hirtus

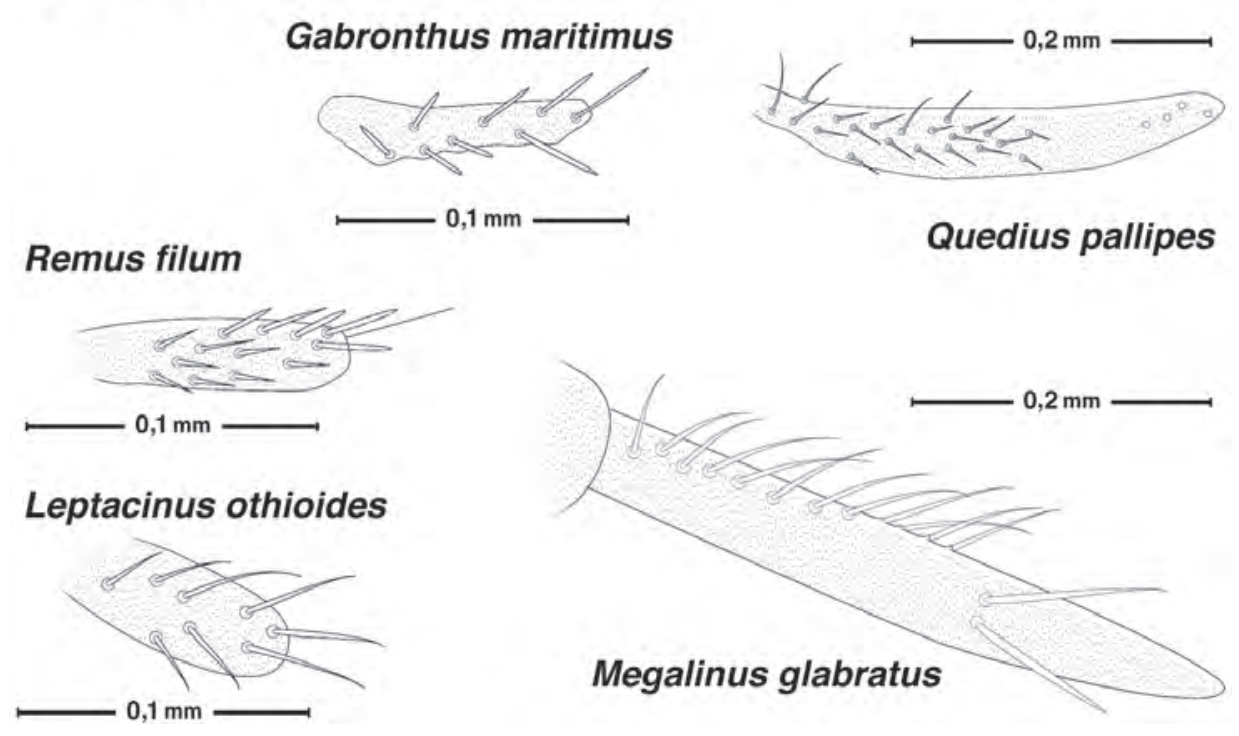

Fig. 2 - Subf. Staphylininae: setigerous lobe in the indicated species of the tribes Staphylinini, Philonthini and Quediini. 


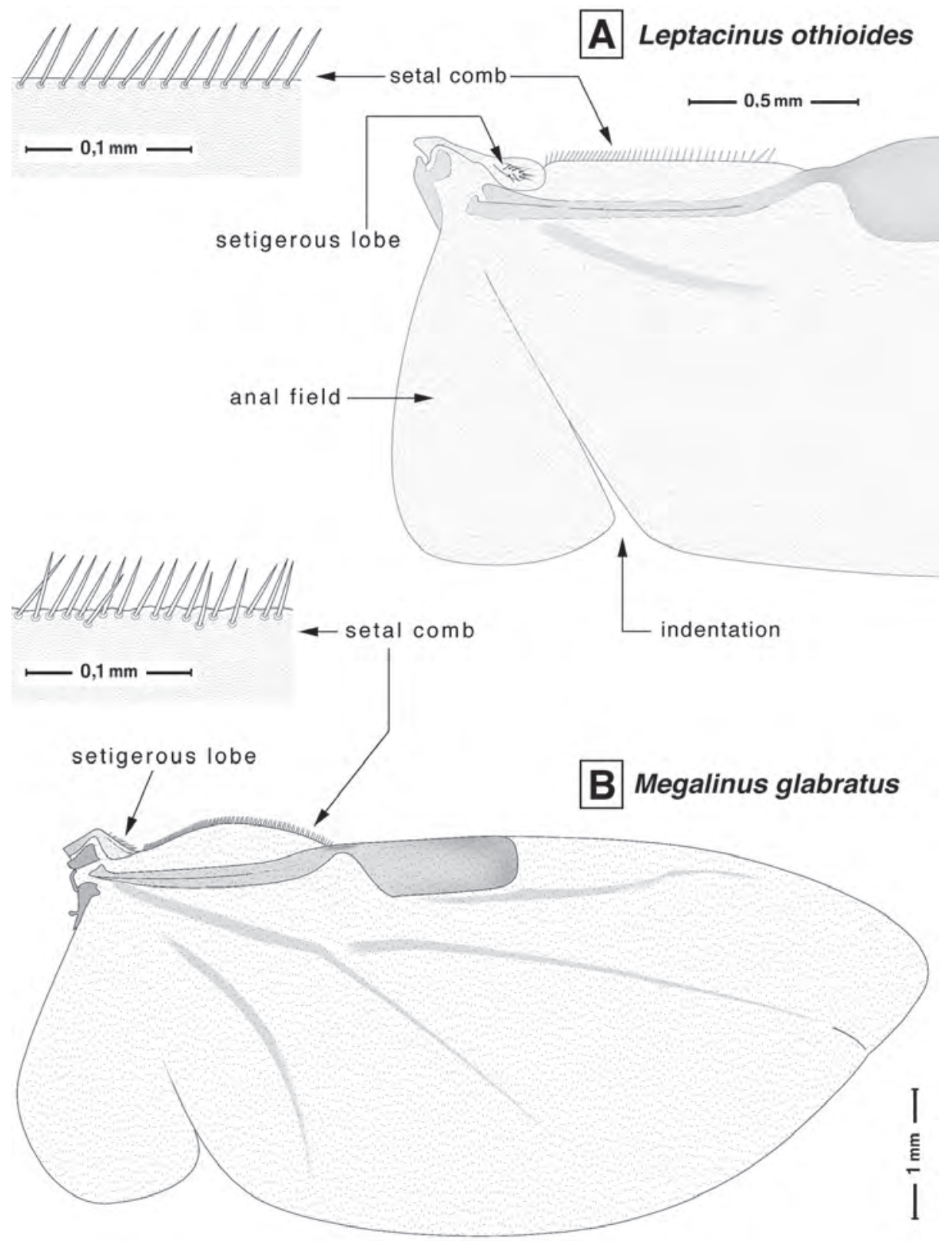

Fig. 3 - Subf. Staphylininae: hind wing details in two species of the tribe Xantholinini. 


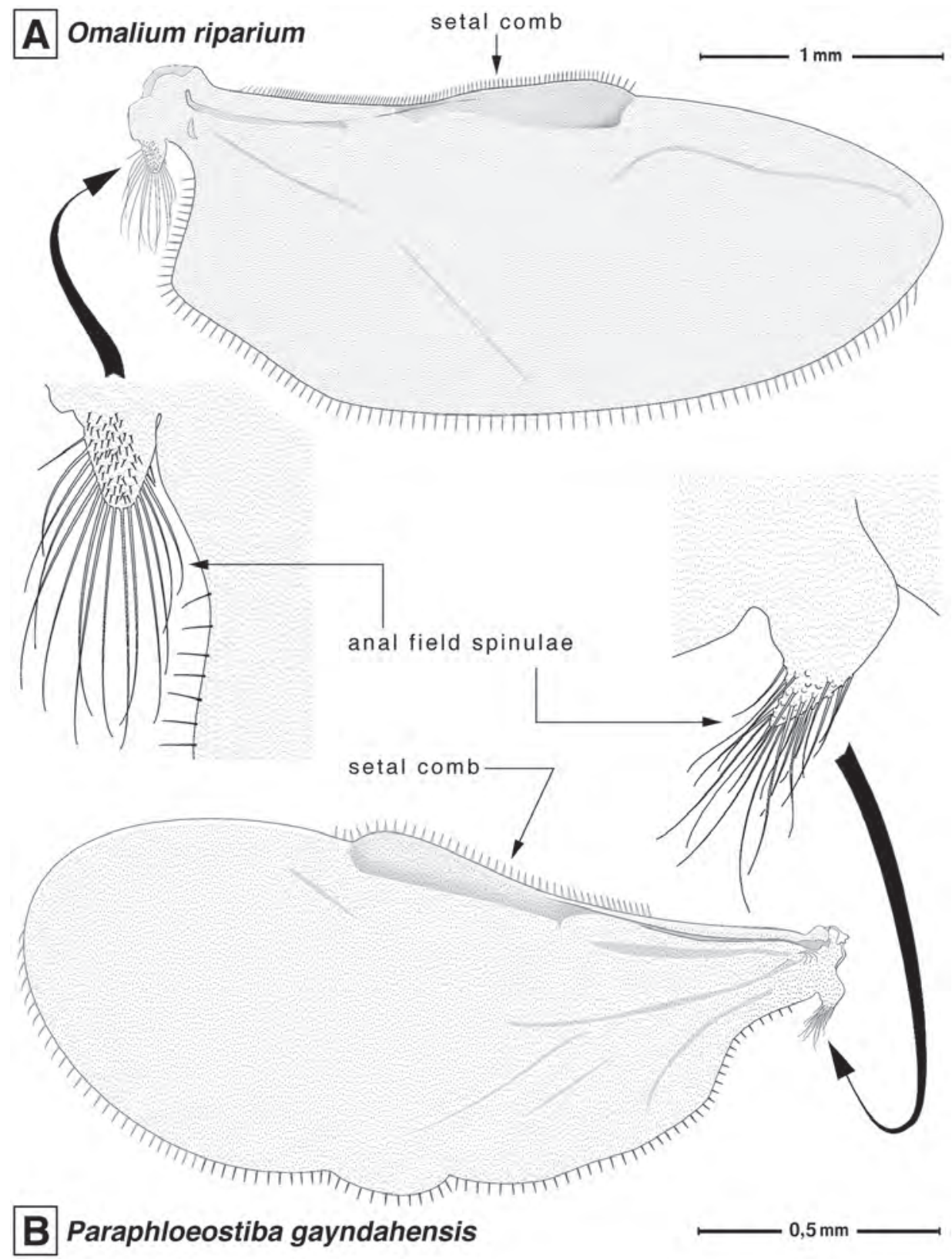

Fig. 4 - Subf. Omaliinae: entire hind wing and details of the anal field in the indicated species. 


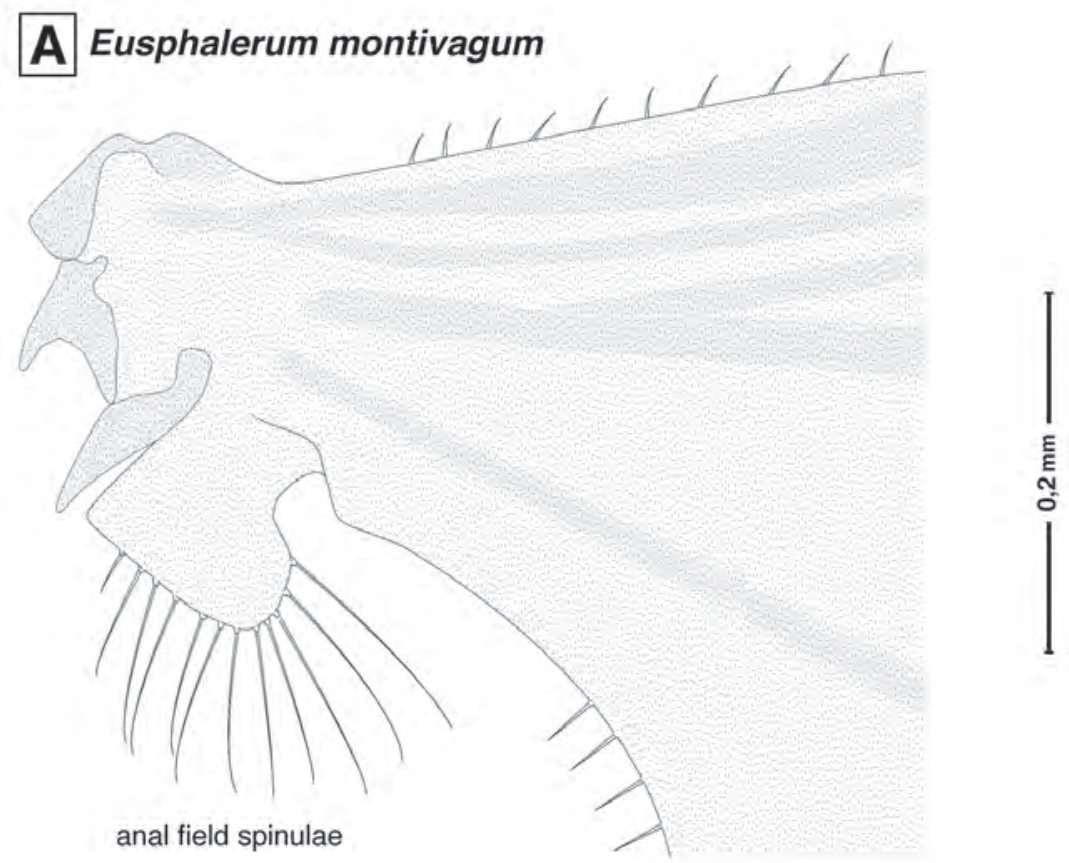

\section{B Stenus longitarsis}

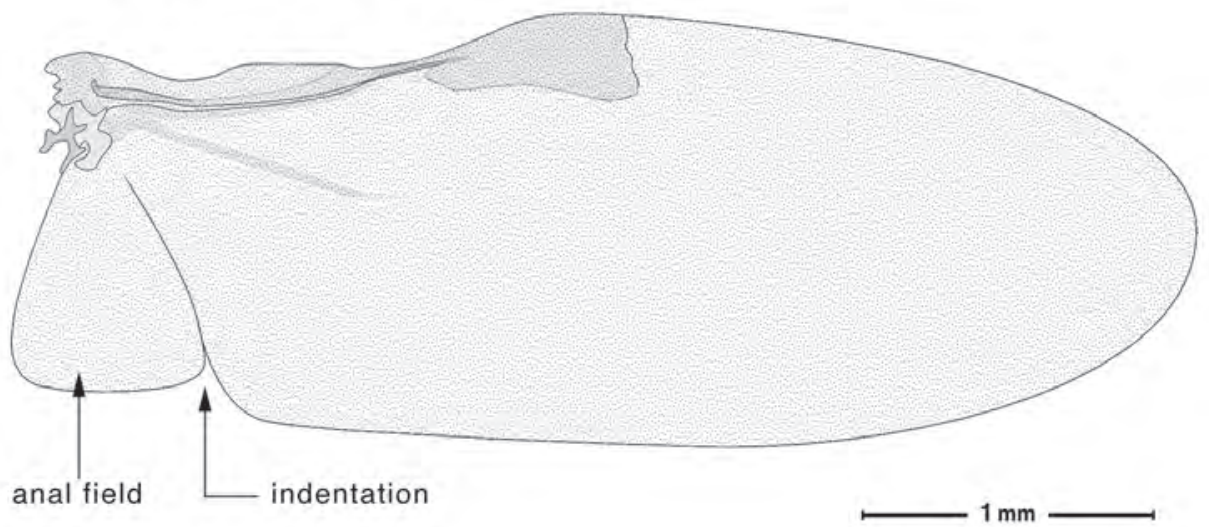

Fig. 5 - Entire hind wing or detail in: A, another species of the subf. Omaliinae; B, a species of the subf. Steninae. 


\section{A Paederus fuscipes}

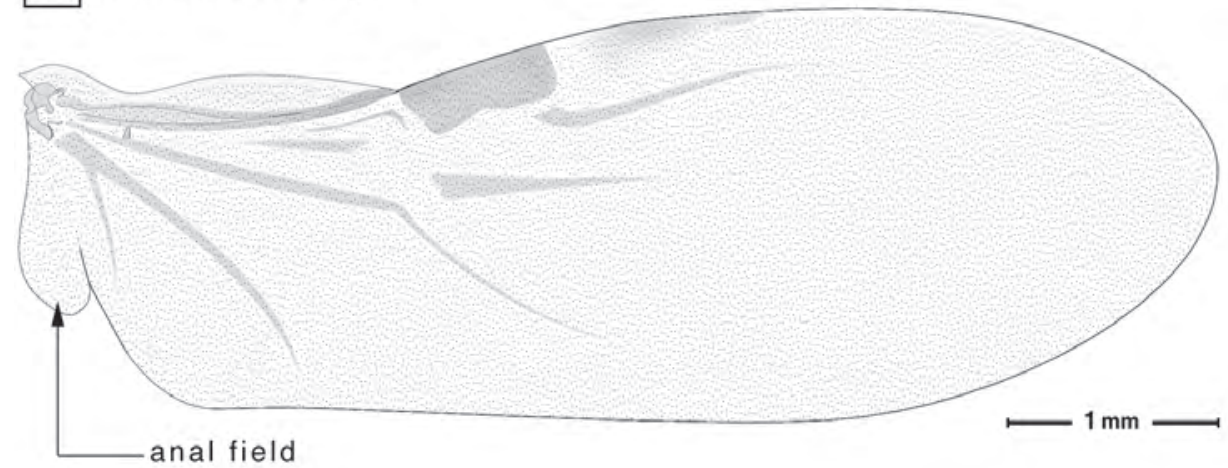

\section{B Pseudolathra lusitanica}

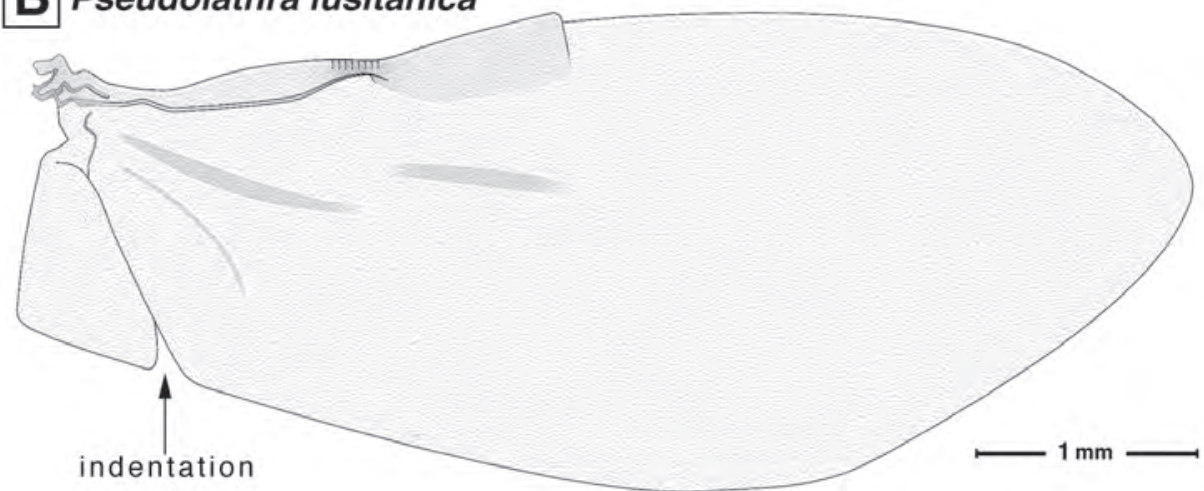

\section{Rugilus orbiculatus}

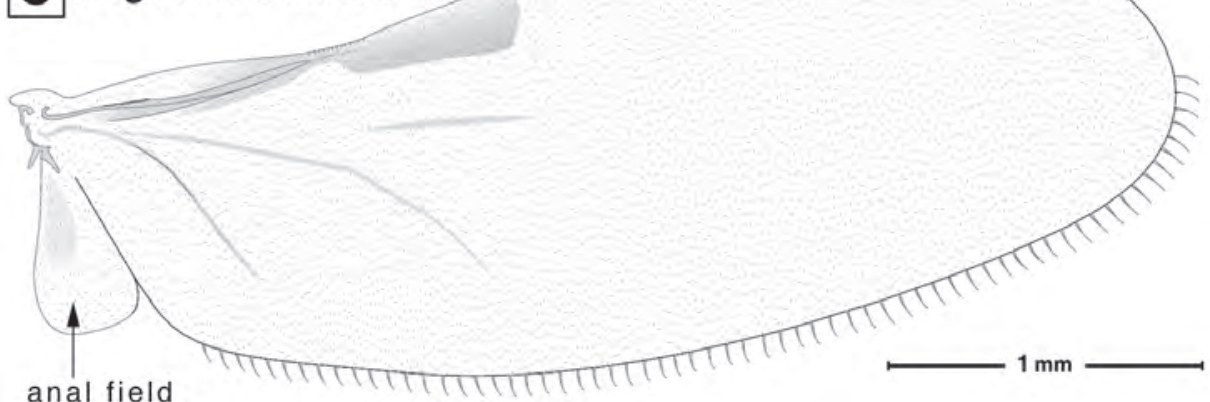
anal field

Fig. 6 - Subf. Paederinae: entire hind wing and details in the indicated species. 

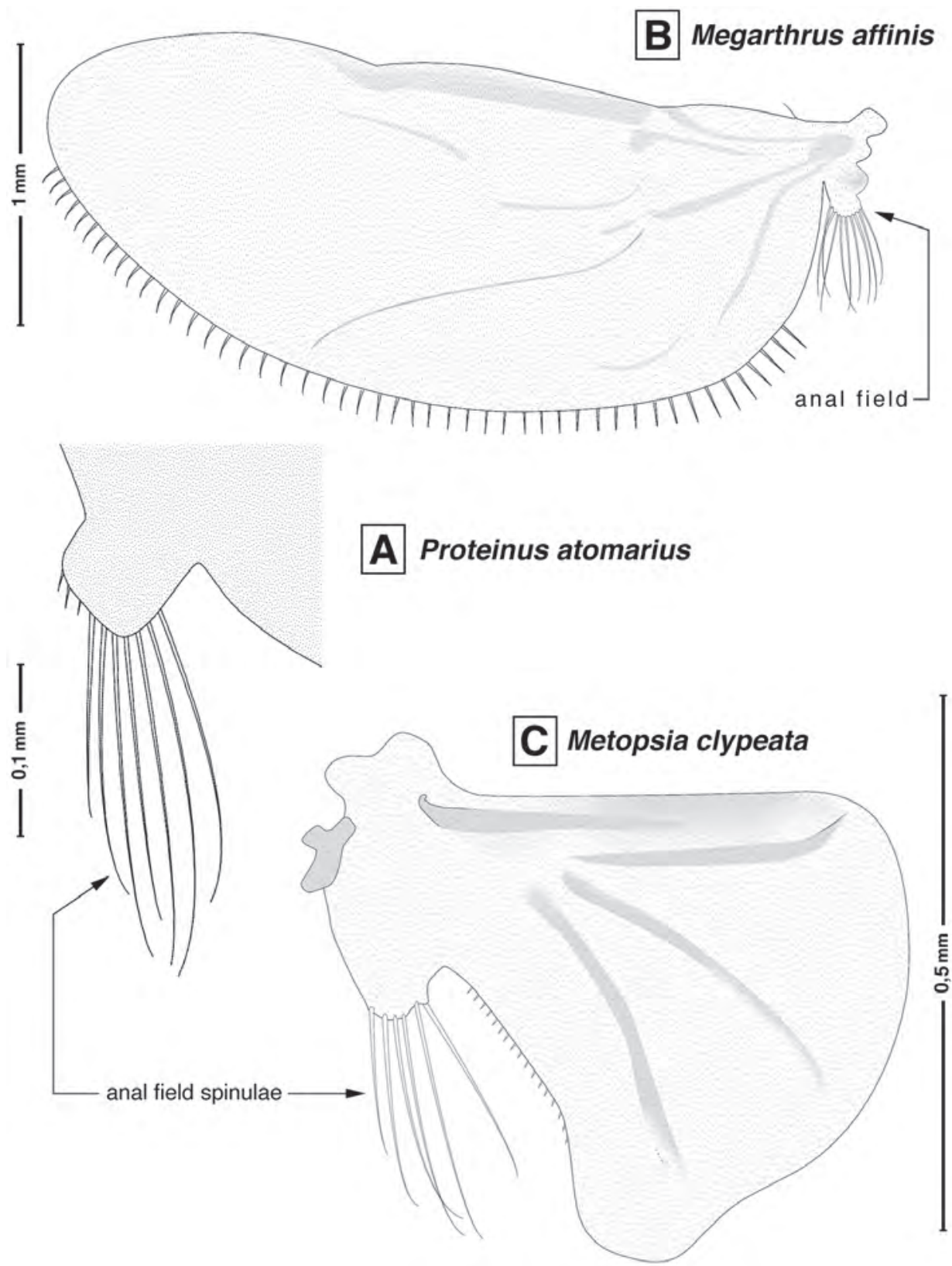

Fig. 7 - Subf. Proteininae: entire hind wing and details in the indicated species. 
wings of Metopsia clypeata; moreover, it can be found in most species of the subfamilies Oxytelinae (Fig. 8), Tachyporinae (Fig. 9) and Aleocharinae. Absence of spinulae has been registered in the following species of these subfamilies: Carpelimus obesus (Oxytelinae), Cilea silphoides (Tachyporinae) (Fig. 9.B), Atheta inquinula, Diestota guadalupensis and Oligota parva (Fig. 10.A) (Aleocharinae). As a whole, data on the anal field are reported in Tab. B.

Tab. B - Presencelabsence and numerical range of the anal field spinulae in each subfamil

\begin{tabular}{|l|c|}
\hline \multicolumn{1}{|c|}{ Subfamily } & No. of spinulae \\
\hline Proteininae (3 species) & $5-10$ \\
\hline Omaliinae (3 species) & $12-20$ \\
\hline Oxytelinae (4 species) & $0-30$ \\
\hline Steninae (2 species) & 0 \\
\hline Paederinae (3 species) & 0 \\
\hline Staphylininae (7species) & 0 \\
\hline Tachyporinae (3 species) & $0-30$ \\
\hline Aleocharinae (14 species) & $0-100$ \\
\hline
\end{tabular}

The number of spinulae within the subf. Aleocharinae (Tab.C) ranges from a single one of Halobrecta flavipes (Fig. 10.B) to about one hundred of Aleochara curtula (Fig. 12.D). Intermediate values belong to the species reported in Fig. 11. Owing to the high number of its spinulae, the anal field of the Aleochara is flabellum-like (Fig. 12.A-C).

\section{CONCLUDING REMARKS}

Opinion of Botturi (1.c.) is that the hind wings of the staphylinids are built in agreement with a defined structural project, which does mechanically improve both wing folding and unfolding through the reduction of the transversal veins. Actually, hind wings of the species examined here exhibit a reduced venation; anyhow, they aren't really uniform for a number of structural details: presence/absence of the setigerous lobe, number of setae of the latter, presence/absence of the setal comb, anal filed sometimes equipment with spinulae. Moreover, two wing structures seem to have a functional role: (I) the setigerous lobe of the Staphylininae, which suggests a mechanical receptor for wing folding, and (II) the flabellum-like anal field of the Aleochara, which likely does affect the flying trim. 


\section{A Oxytelus piceus}

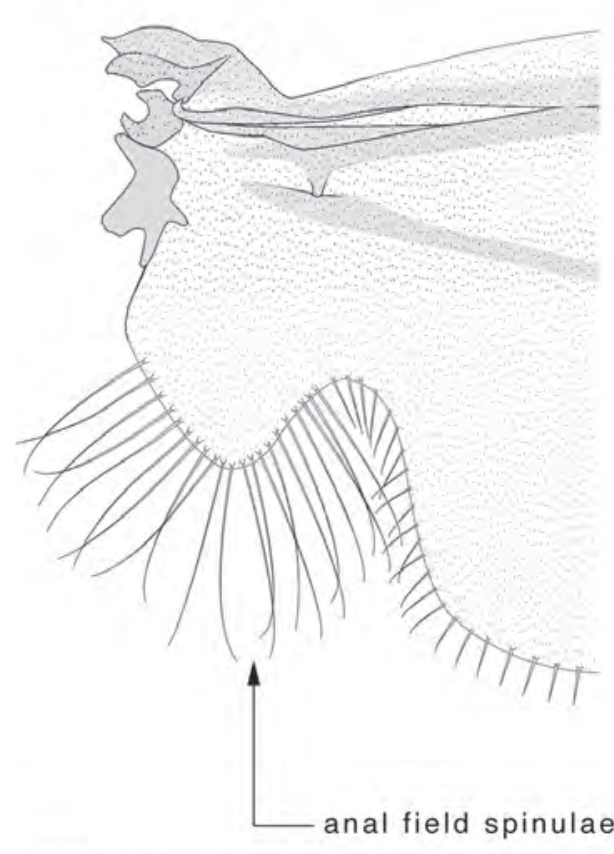

B Bledius furcatus

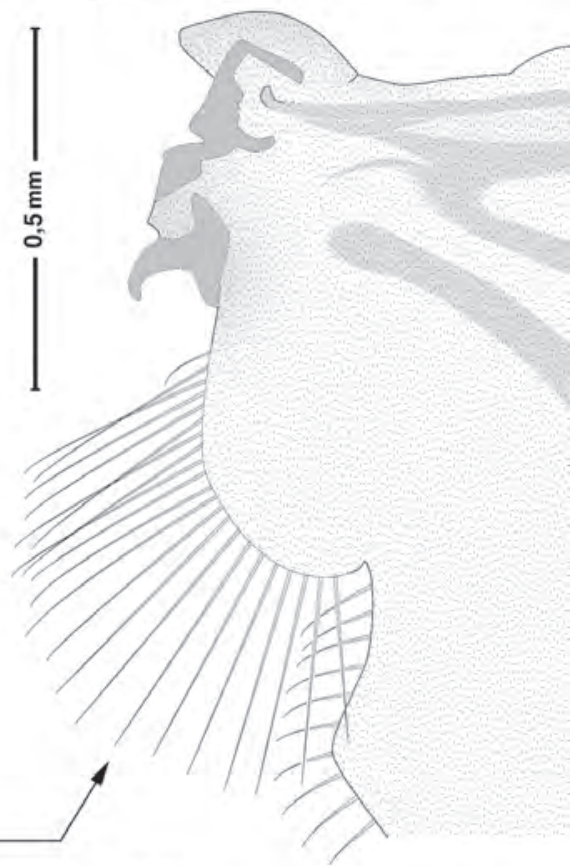

\section{Platystethus nitens}

D Anotylus inustus
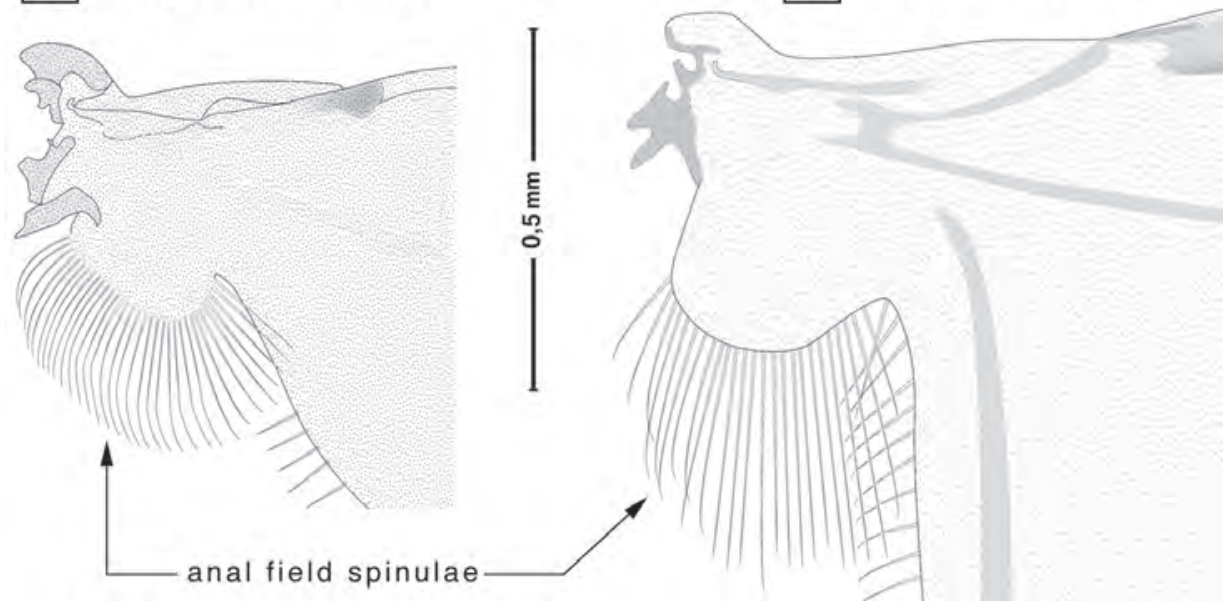

Fig. 8 - Subf. Oxytelinae: details of hind wings provided with anal field spinulae in the indicated species. 


\section{A Tachyporus hypnorum}

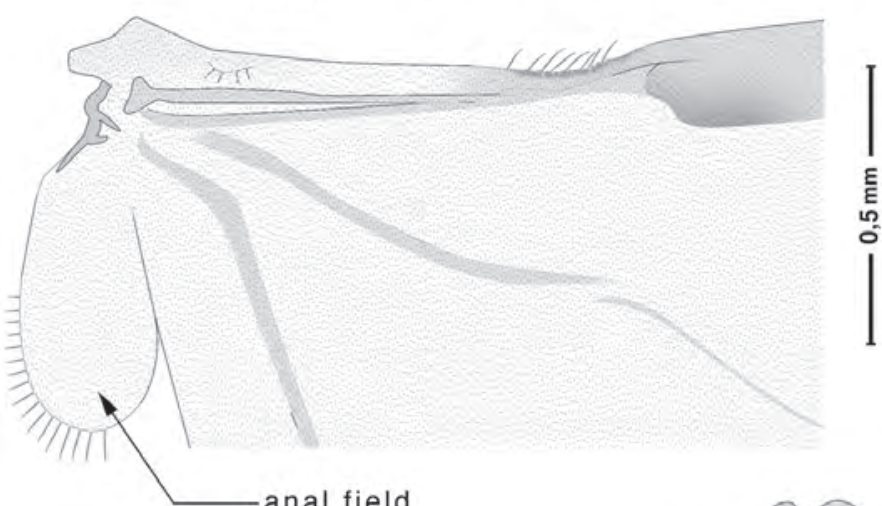

anal field

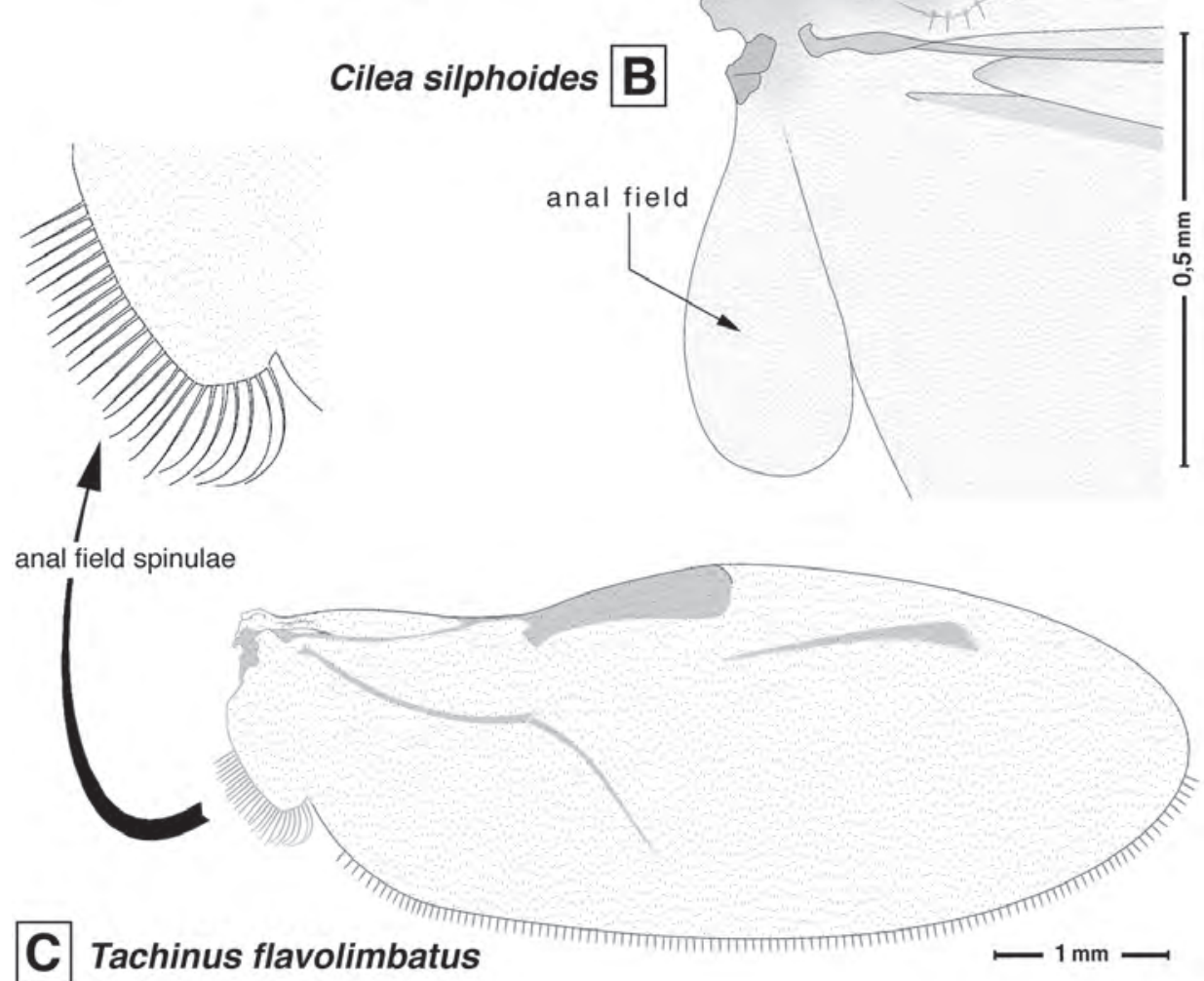

Fig. 9 - Subf. Tachyporinae: details of hind wings provided with anal field spinulae in the indicated species. 


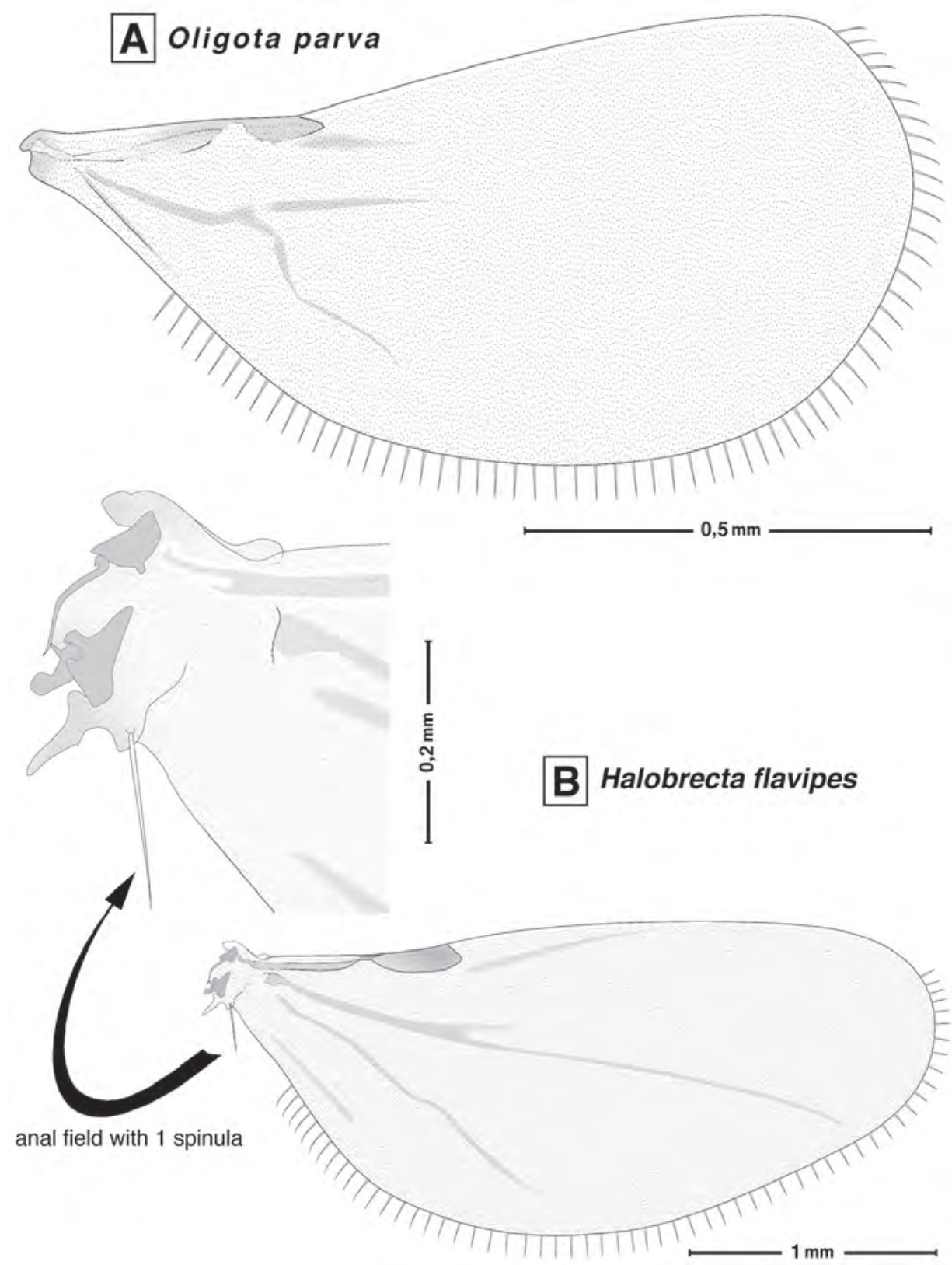

Fig. 10 - Subf. Aleocharinae: A, instance of hind wings without distinct anal field; B, hind wing bearing a single spinula at its anal field. 


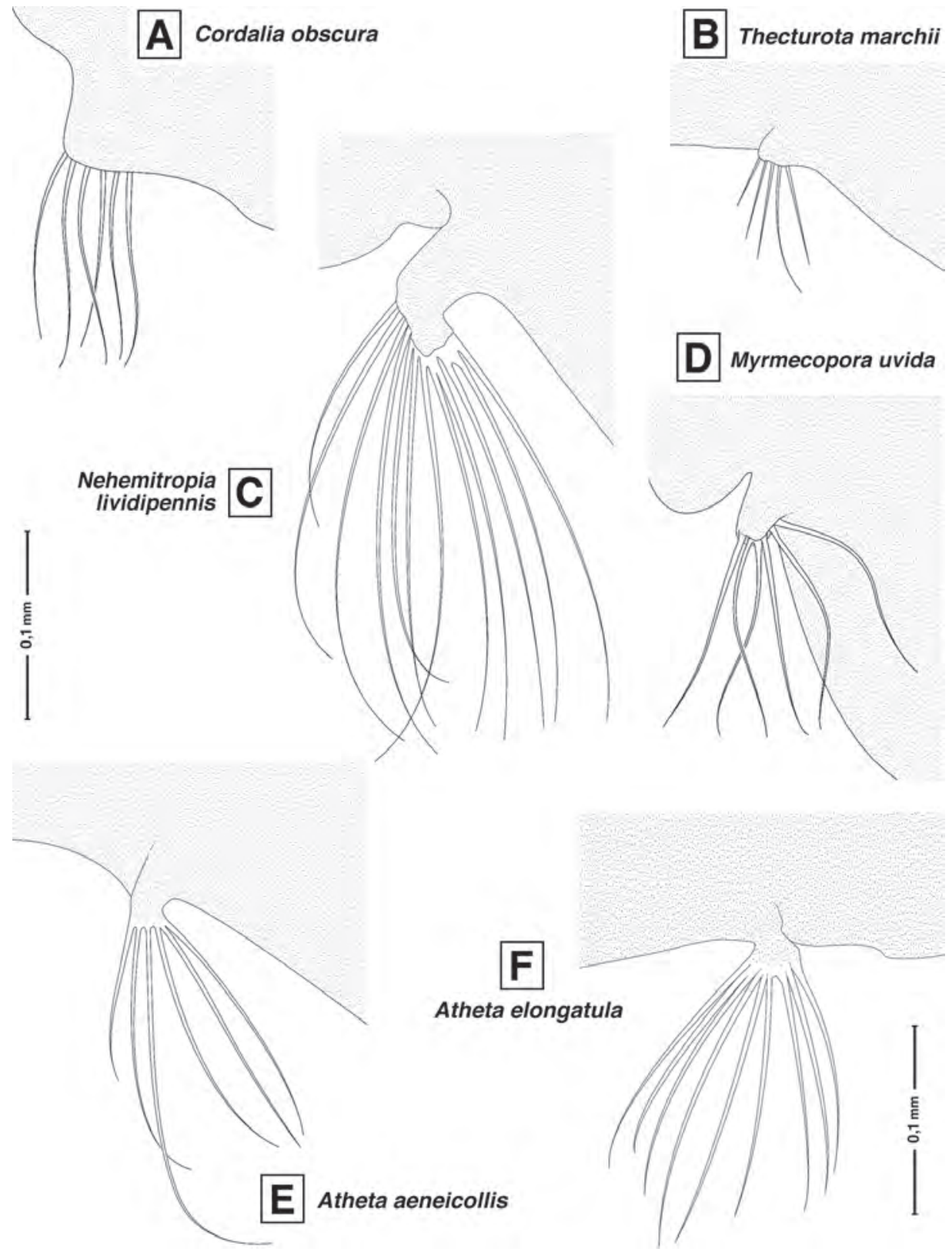

Fig. 11 - Subf. Aleocharinae: hind wings provided with 5-12 spinulae at the anal field. 

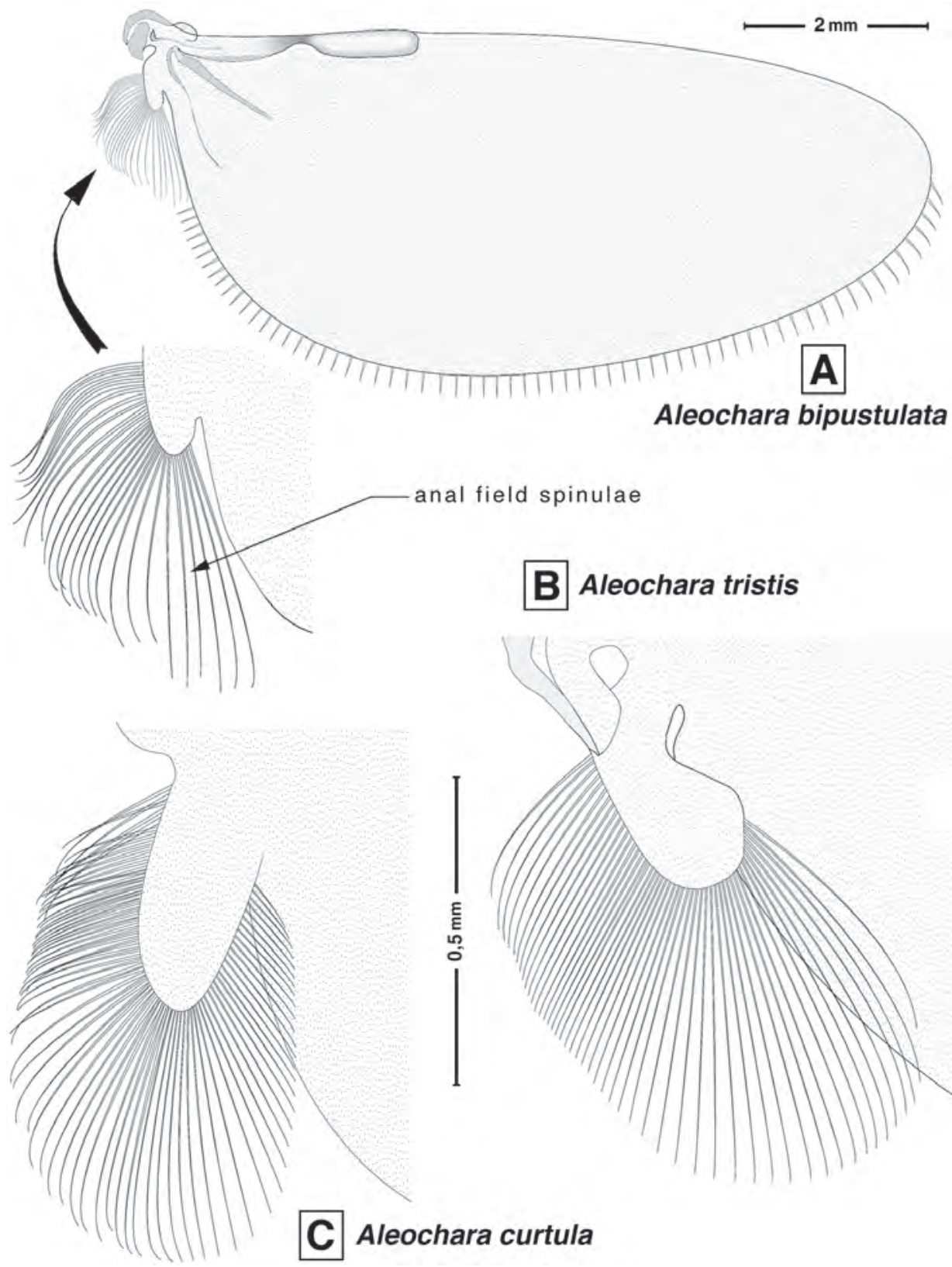

Fig. 12 - Subf. Aleocharinae: entire hind wings and details of the anal field in the examined species of the genus Aleochara. 
Tab.C-Presencelabsence and numerical range of the anal field spinulae in the subf. Aleocharinae according to species.

\begin{tabular}{|l|c|}
\hline \multicolumn{1}{|c|}{ Examined species } & No. of spinulae \\
\hline Aleochara bipustulata & about 30 \\
\hline Aleochara curtula & about 100 \\
\hline Aleochara tristis & about 60 \\
\hline Atheta aeneicollis & 7 \\
\hline Atheta elongatula & 9 \\
\hline Atheta inquinula & 0 \\
\hline Cordalia obscura & 6 \\
\hline Diestota guadalupensis & 0 \\
\hline Halobrecta flavipes & 1 \\
\hline Myrmecopora uvida & 6 \\
\hline Nehemitropia lividipennis & 12 \\
\hline Oligota parva & 0 \\
\hline Thecturota marchii & 5 \\
\hline Trichiusa immigrata & 5 \\
\hline
\end{tabular}

\section{REFERENCES}

BotTURI A., 1978 - L'ala metatoracica dei Coleotteri Stafilinidi: adattamenti e convergenze. Atti XI Congr. naz. ital. Entomol., Portici-Sorrento 10-15 Maggio 1978, pp. 109-113.

BRowne D.J., SCHOLTZ C.H., 1994 - The morphology and terminology of the hindwing articulation and wing base of the Coleoptera, with special reference to Scarabaeoidea. - System. Entomol., 19: 133-143.

Ciceroni A., Puthz V., Zanetti A., 1995 - Coleoptera Polyphaga III. Staphylinidae. - In: Minelli A., Ruffo S., La Posta S. (eds.), Checklist delle specie della fauna italiana, Calderini ed., Bologna, fasc. 48, 65 pp.

CROwson R.A., 1967 - The natural classification of the families of Coleoptera. - E.W. Classey ltd., Hampton, 214 pp.

D'Orchimont A., 1920 - La nervation alaire des Coléoptères. - Ann. entomol. Soc. France, 89: 1-50.

Forbes W.T.M., 1922 - The wing venation of the Coleoptera. - Ann. entomol. Soc. Am., 15: 328-352.

Graham S.A., 1922 - A study of the wing-venation of the Coleoptera. - Ann. entom. Soc. Am., 15: 191-200.

HAMMOND P.M., 1979 - Wing-folding mechanisms of beetles, with special reference to investigations of adephagan phylogeny. - In: Erwin \& al. eds., Carabid beetles, their evolution, natural history and classification. - Proc. 1st Int. Symp. Carabidology, Washington, The Hague, Junk, pp. 113-180. 
KuKalova'-Peck J., Lawrence J.F., 1993 - Evolution of the hind wing in Coleoptera. - Canadian Ent., 125: 181-258.

Smetana A., 2004 - Staphylinoidea. - In: Löbl I. \& Smetana A. (eds), Catalogue of Palaearctic Coleoptera, vol. 2, Apollo Books, 942 pp.

WALLACE F.L., FOX R.C., 1975 - A comparative morphological study of the hind wing venation of the order Coleoptera. Part I. - Proc. Entomol. Soc. Washington, 77: 329-354.

LuIGI De MARzo, via F. Turati 3, I-70016 Noicàttaro (BA), e-mail:1.demarzo@alice.it Accepted 22 October 2010 